(C) Romanov P. Yu., Romanova N.A., 2021, Journal of Oceanological Research, 2021, Vol. 49, No. 4, P. 63-85

\title{
SEA-LEVEL PRESSURE TRENDS IN THE SOUTHERN OCEAN AND ANTARCTICA FROM REANALYSIS AND IN SITU DATA
}

\author{
Romanov P. Yu. ${ }^{1}$, Romanova N.A. ${ }^{2}$ \\ ${ }^{1}$ NOAA-CREST, City University of New York, New York, NY 10031, USA \\ e-mail:peter.romanov@noaa.gov \\ ${ }^{2}$ Shirshov Institute of Oceanology, Russian Academy of Sciences, \\ 36, Nakhimovskiy prospekt, Moscow, 117997, Russia, \\ e-mail: romanova@ocean.ru \\ Submitted 22.08.2021, accepted 15.12.2021.
}

\begin{abstract}
Trends in the mean sea-level pressure (SLP) in Antarctica in the last four decades (19802020) have been examined using in situ observations and reanalysis data. The analysis involved time series of monthly mean, season-mean and yearly-mean values of the SLP derived from four reanalysis datasets, NCEP/NCAR, ERA5, JRA55, MERRA2, and from surface observations acquired from the Reference Antarctic Data for Environmental Research (READER) dataset. With this data we have evaluated the trends, characterized their seasonal peculiarities and variation across the high-latitude region of the Southern Hemisphere. The results of the analysis confirmed the dominance of decreasing trends in the annual mean SLP in Antarctica. Larger negative trends were found in the Western Antarctica with the most pronounced pressure drop in the South Pacific. The long-term decrease in the annual mean SLP in Antarctica was due to strong negative pressure trends in the austral summer and fall season whereas in winter and in spring the trends turn to mixed and mostly positive. The comparison of multiyear time series of SLP reanalysis data with in situ observations at Antarctic stations revealed a considerable overestimate of negative SLP trends in the NCEP/NCAR dataset. Among the four examined reanalysis datasets, ERA5 provided the best agreement with the station data on the annual mean and monthly mean SLP trend values.
\end{abstract}

Keywords: Reanalysis datasets, Antarctic region, mean sea-level pressure, trends, in situ observations

\section{Introduction}

Long-term variation and trends of climate parameters in the high-latitude Southern Ocean and over the Antarctic continent attract a considerable attention of climatologists, atmospheric, oceanic and environmental scientists. Strong albedo and low temperatures throughout the year make this region one of critical elements in the Earth's climate system which to a large extent determines weather and climate processes in lower latitudes of the Southern Hemisphere and even across the equator (Ho et al., 2005). In recent years several high temperature records have been set in the Antarctic Peninsula suggesting a possible warming of high latitudes of the Southern Hemisphere (Carril et al., 2005; Bromwich et al., 2014). Increasing wind speed along the Antarctic coast in the last several 
decades have been documented indicating a possible increase in the cyclonic activity (Yu et al., 2020; Romanova, Romanov 2019). There are reports of changing precipitation amounts and, correspondingly snow accumulation in Antarctica along with the general atmospheric circulation patterns (Marshall et al., 2017). These changes have an immediate implication for the marine and continental wildlife in the region (Smith et al., 2017), for other environmental variables in Antarctica, particularly, for the sea ice concentration (Hobbs et al., 2020), glacier dynamics (Cook et al., 2016) and the ocean salinity (Menezes et al., 2017), as well as for a wide range of climate characteristics of Southern Hemisphere midlatitudes (e.g., Meneghini et al., 2007).

Sea-level pressure presents one of the major weather and climate elements. In the Southern Hemisphere a meridional gradient between the high pressure in midlatitudes and the belt of low pressure in high latitudes characterizes the leading pattern of climate variability in the Southern Hemisphere high latitudes known as the Southern Annual Mode (SAM) or Antarctic Oscillation. The Southern Annual Mode determines to a large extent the intensity and the north-south movement of near-surface westerly winds circling Antarctica (e.g., Lovenduski and Gruber, 2005) and, hence, the ocean currents, the air-sea heat exchange, precipitation patterns, sea ice variability and the ice sheet stability (e.g., Lefebvre et al., 2004). According to Fogt and Marshall, (2020) between 22 to $34 \%$ of the variability in the extratropical atmospheric circulation is explained by the SAM. A positive phase of SAM is associated with lower pressure in the Southern Hemisphere high latitudes, higher pressure in midlatitudes, strengthening and poleward contraction of the subpolar belt of westerly winds. Conversely a negative SAM phase implies weakening of the meridional pressure gradient and expansion of the belt of westerly winds towards the equator (Marshall et al., 2006). Because of a relatively smaller variability of the sea-level pressure in the subtropical and midlatitude Southern Hemisphere on a decadal time scale (e.g., Romanova, Romanov, 2020), long-term changes in the state of SAM are mostly determined by variation of SLP in the polar area.

Studies of the Antarctic climate variability using reanalysis datasets and climate models agree on an overall decrease of SLP in the Antarctic region in the last decades indicating a persisting positive phase of SAM (Thompson and Solomon, 2002). Similar general decreasing tendency has been seen in the time series of instrumental SLP measurements at Antarctic weather stations (Turner et al., 2005). In the course of the year most pronounced negative SLP trends appear to be associated with the summer season (Fogt et al., 2017). Location wise stronger pressure decrease over time was reported in the area of the Amundsen Sea Low incorporating Amundsen, Bellingshausen and Ross Sea (Schmidt and Grise, 2017; Turner et al., 2013).

The particular magnitude and the exact distribution of the trends across the region, however, remains arguable. This is due to a strong spatial and seasonal heterogeneity of the trends and a considerable spread in their estimates among the datasets (e.g., O'Connor et al., 2021). The spread in the estimated trend values can be partially explained by different time periods examined in the studies and by different duration of the datasets. 
Available trend estimates are based on the records ending mostly in the beginning or in the middle of 2000s. Therefore, they may not account for possible most recent changes in the Antarctic climate. Another factor contributing to the uncertainty in the SLP trends consists in the differences between various reanalysis schemes. The latter include specific features of physical models incorporated in the reanalysis schemes, differences in the type and in the scope of assimilated observation data and in the data assimilation procedure. Validation against in situ observations presents the only viable way to assess the performance of various reanalysis schemes, to evaluate the accuracy of model-generated datasets and of the corresponding long-term trends. So far only few efforts have been made to quantitatively intercompare different reanalysis schemes and in situ instrumental measurements with respect to the SLP trends in the Antarctic region. (e.g., Fogt et al., 2017, O’Connor et al., 2021).

In this study we examine information on the sea-level pressure (SLP) over the last four decades available from a set of state-of-the-art atmospheric reanalysis datasets. The principal objective of the work was to infer and quantify SLP trends over the high-latitude portion of the Southern Ocean and over the Antarctic continent using the most up to date information on this meteorological variable. We focus on regional and seasonal patterns of the trends and identify similarities and differences between the datasets with respect to the SLP trend characterization. We further use the results of historical in situ observations at Antarctic weather stations to assess realism and accuracy of reanalysis datasets in reproducing long-term changes of SLP across Antarctica.

\section{Data and Methodology}

In this paper we have used monthly-averaged mean sea-level pressure (SLP) data from the following four global atmospheric reanalysis datasets, the National Centers for Environmental Prediction and National Center for Atmospheric Research (NCEP/ NCAR), the fifth generation atmospheric reanalysis of European Centre for Medium-Range Weather Forecasts, ECMWF (ERA5), the Japanese 55-year reanalysis created by the Japan Meteorological Agency, JMA (JRA55) and NASA Second Modern Era Retrospective-Analysis for Research and Application (MERRA2). The main properties of the datasets are summarized in Table 1.

The NCEP/NCAR reanalysis uses the NCEP global spectral model operational in 1995 and a three-dimensional variational (3DVAR) assimilation scheme (Kalnay et al., 1996). The output dataset is made available as regular latitude-longitude grids of atmospheric and surface variables at $2.5^{\circ} \times 2.5^{\circ}$ resolution. It is kept current and spans back to the beginning of 1948. A 3DVAR approach also comprises the core of the Goddard Earth Observing System Data Assimilation System Version 5 (GEOS-5) used in the NASA's MERRA2 reanalysis (Gelaro et al., 2017). The gridded dataset of MERRA2 variables is provided at finer spatial resolution of $0.5^{\circ}$ latitude $\times 0.625^{\circ}$ longitude. It is continuously updated and covers the time period from 1981 to the present. ERA5 is the most recent 
climate reanalysis scheme developed at ECMWF. It uses the 2016 version of the ECMWF Integrated Forecast Model (IFS) with the data assimilation based on the four-dimensional variational analysis, 4DVAR (Hersbach et al., 2018). With $0.25^{\circ}$ by $0.25^{\circ}$ global grid cell size of output products, ERA5 provides the highest spatial resolution among all four reanalysis datasets included in this study. JRA55 (Kobayashi et al., 2015) is the second reanalysis of the Japan Meteorological Agency based on an improved version of the JMA 4DVAR data assimilation and prediction system. JRA55 global gridded output products at the spatial resolution of $1.25^{\circ} \times 1.25^{\circ}$ are routinely generated and are available back to 1958.

As a source of in situ data in Antarctica we have used the Reference Antarctic Data for Environmental Research (READER) dataset (http://www.antarctica.ac.uk/met/ READER/) of the British Antarctic Survey. The READER dataset incorporates observations of the air temperature, wind speed and sea/surface level pressure collected at more than 30 Antarctic stations and provides them as monthly mean values. The available time series of the sea-level pressure start mostly in the early-mid 1950s, but go back to the beginning of the $20^{\text {th }}$ century at some locations.

Table 1. Characteristics of global atmospheric reanalysis datasets used in the study

\begin{tabular}{|l|c|c|c|c|c|}
\hline \multicolumn{1}{|c|}{ Reanalysis } & Source & Citation & Period & $\begin{array}{c}\text { Assimilation } \\
\text { system }\end{array}$ & Horizontal grid \\
\hline NCEP/NCAR & NOAA & Kalnay et al. (1996) & 1948-present & 3DVAR & $2.5^{\circ} \times 2.5^{\circ}$ \\
\hline ERA5 & ECMWF & Hersbach et al. (2018) & 1979-present & 4DVAR & $0.25^{\circ} \times 0.25^{\circ}$ \\
\hline JRA55 & JMA & Kobayashi et al. (2015) & 1958-current & 4DVAR & $1.25^{\circ} \times 1.25^{\circ}$ \\
\hline MERRA2 & NASA & Gelaro et al. (2017) & 1980-current & 3DVAR & $0.5^{\circ} \times 0.625^{\circ}$ \\
\hline
\end{tabular}

For the analysis we have selected stations featuring complete or near-complete time series of the monthly mean sea-level pressure. These stations are listed in Table 2. As "near-complete" we defined time series where gaps in the monthly SLP records affected less than 6 years or about 15\% of all years during the 1980-2020 time period. Most of the selected stations are located in the Antarctic Peninsula and in the coastal areas of the Indian Ocean Sector $\left(30^{\circ} \mathrm{E}-40^{\circ} \mathrm{E}\right)$ and of the Atlantic Ocean Sector $\left(70^{\circ} \mathrm{W}-30^{\circ} \mathrm{E}\right)$ of the Antarctic continent (see Figure 1). At two high-elevation stations, Amundsen Scot and Vostok only surface-level pressure records were available, not the sea-level pressure.

In this work reanalysis and in situ monthly mean SLP data over the 41-year period were applied to produce time series of corresponding season and annual mean values. In the in situ dataset seasonal and annual means were calculated for years where monthly records were available correspondingly for all three months of the season and for all twelve months of the year. Trends in the SLP were calculated using a linear regression technique based on the least squares method. Other statistical data analysis techniques included Pearson correlation and the root-mean-square deviation (RMSD). 
Journal of Oceanological Research. 2021. Vol. 49. No. 4. P. 63-85

Table 2. Antarctic stations used in the study

\begin{tabular}{|c|l|c|c|c|c|c|}
\hline No. & \multicolumn{1}{|c|}{ Station Name } & Latitude & Longitude & Elevation, $\mathrm{m}$ & Region $^{1}$ & $\begin{array}{c}\text { Full years } \\
\text { of data records }\end{array}$ \\
\hline 1 & Bellingshausen & $66.2^{\circ} \mathrm{S}$ & $58.9^{\circ} \mathrm{W}$ & 16 & AP & 41 \\
\hline 2 & Casey & $66.3^{\circ} \mathrm{S}$ & $110.5^{\circ} \mathrm{E}$ & 42 & AS & 40 \\
\hline 3 & Davis & $68.6^{\circ} \mathrm{S}$ & $78.0^{\circ} \mathrm{E}$ & 13 & IS & 40 \\
\hline 4 & Esperanza & $63.4^{\circ} \mathrm{S}$ & $57.0^{\circ} \mathrm{W}$ & 13 & AP & 40 \\
\hline 5 & Faraday & $65.4^{\circ} \mathrm{S}$ & $64.4^{\circ} \mathrm{W}$ & 11 & AP & 41 \\
\hline 6 & Halley & $75.5^{\circ} \mathrm{S}$ & $26.4^{\circ} \mathrm{W}$ & 30 & AS & 39 \\
\hline 7 & Macquarie & $54.5^{\circ} \mathrm{S}$ & $158.9^{\circ} \mathrm{E}$ & 8 & PS & 37 \\
\hline 8 & Marambio & $64.2^{\circ} \mathrm{S}$ & $56.7^{\circ} \mathrm{W}$ & 198 & AP & 38 \\
\hline 9 & Mawson & $67.6^{\circ} \mathrm{S}$ & $62.9^{\circ} \mathrm{E}$ & 16 & IS & 39 \\
\hline 10 & Mirny & $66.5^{\circ} \mathrm{S}$ & $93.0^{\circ} \mathrm{E}$ & 30 & IS & 38 \\
\hline 11 & Neumayer & $70.7^{\circ} \mathrm{S}$ & $8.4^{\circ} \mathrm{W}$ & 50 & AS & 38 \\
\hline 12 & Novolazarevskaya & $70.8^{\circ} \mathrm{S}$ & $11.8^{\circ} \mathrm{E}$ & 119 & AS & 40 \\
\hline 13 & Rothera & $67.5^{\circ} \mathrm{S}$ & $68.1^{\circ} \mathrm{W}$ & 32 & AP & 40 \\
\hline 14 & Syowa & $69.0^{\circ} \mathrm{S}$ & $39.6^{\circ} \mathrm{E}$ & 21 & IS & 41 \\
\hline 15 & Amundsen Scott & $90.0^{\circ} \mathrm{S}$ & $0.0^{\circ} \mathrm{W}$ & 2835 & IA & 39 \\
\hline 16 & Dumont Durville & $66.7^{\circ} \mathrm{S}$ & $140.0^{\circ} \mathrm{E}$ & 43 & IS & 35 \\
\hline 17 & Scott Base & $77.9^{\circ} \mathrm{S}$ & $166.7^{\circ} \mathrm{E}$ & 16 & PS & 36 \\
\hline 18 & Vostok & $78.5^{\circ} \mathrm{S}$ & $106.9^{\circ} \mathrm{E}$ & 3490 & IA & 35 \\
\hline
\end{tabular}

${ }^{1}$ Region codes are as follows: AP - Antarctic Peninsula, IS - Indian Ocean Sector of Antarctica, AS - Atlantic Ocean Sector of Antarctica, PS - Pacific Ocean Sector, IA - Inner Antarctica.

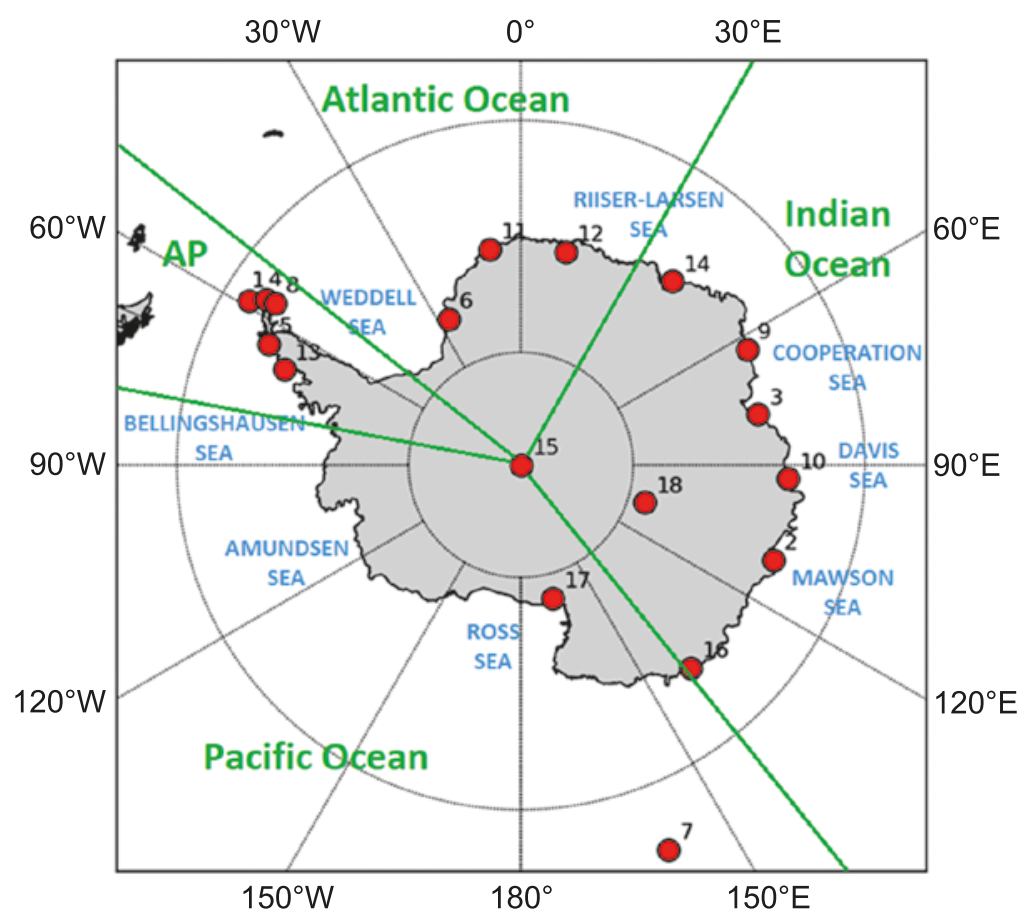

Fig. 1. Location of Antarctic weather stations used in the study. Station names and auxiliary information on the stations is provided in Table 1. AP stands for Antarctic Peninsula 


\section{Results \\ Sea-level pressure and trends from reanalysis datasets}

Figure 2 presents the multiyear annual mean SLP in the high latitude region of the Southern Hemisphere derived from the four reanalysis datasets, NCEP/NCAR, ERA5, JRA55 and MERRA2. As seen from the charts, there is a noticeable similarity between the datasets on the magnitude of the mean pressure over the open ocean and over the Antarctic coastal area. The datasets reveal a similar spatial structure of the SLP distribution with a clearly identifiable Antarctic belt of low pressure within approximately $60^{\circ}-70^{\circ} \mathrm{S}$, typically referred to as the Antarctic circumpolar pressure trough (ACT) and three distinct pressure "lows" with the depth below $980 \mathrm{hPa}$ along the ACT centered at Amundsen, Riiser-Larsen and Davis seas. Throughout the year ACT migrates within several degree latitude of its annual mean position (see the two dashed lines in the plots indicating the mean southernmost and the mean northmost location of ACT). As also seen from Figure 2, the meridional range of the ACT seasonal migration noticeably decreases from the West of the Southern Ocean to the East. This is consistent with the results of storm track analyses in the region (e.g., Uotila et al., 2011; Hodges et al., 2011) which suggest a generally higher cyclone track density, and hence, their smaller spatial spread, in the Eastern sector of the Southern Ocean. Over the continent, particularly over Eastern Antarctica the agreement between the four reanalysis datasets on the annual mean SLP noticeably deteriorates. The differences are apparently due to the high surface elevation of the inner continent and correspondingly to large uncertainties associated with extrapolating the estimated surface pressure to the mean sea level.

As well as the long-term means, the reanalysis datasets demonstrate a good agreement on the year-to-year changes of the sea-level pressure. This is seen in particular from Figure 3 which shows time series of the annual mean SLP values estimated over the ACT region. Spatial averaging of the pressure data was performed within the area bounded by the mean most northern and most southern location of the ACT (shown in Figure 2). As evident from Figure 3, all datasets agree on an overall "deepening" of the ACT in the last four decades and on a faster pressure drop with time in the Western than in the Eastern sector of the Southern Ocean. However, particular rates of the pressure change with time vary between the reanalysis products. While ERA5 and MERRA2 yield close values of the trends ranging from -0.025 to -0.028 $\mathrm{hPa} /$ year in the Eastern sector and from -0.045 to $-0.050 \mathrm{hPa} /$ year in the Western sector, trends inferred from JRA55 and NCEP/NCAR were about two times smaller and about two times larger, respectively. Dominating decreasing pressure trends in the high-latitude ACT region are clearly indicative of the strengthening of SAM observed in the last decades (e.g., Fogt and Marshall, 2020).

Further analysis of the results in Figure 3 reveals a nonuniformity in the ACT mean sea-level pressure changes over the four decades with somewhat faster pressure decrease in the 1980s and 1990s. This particularly concerns Eastern Antarctica where 

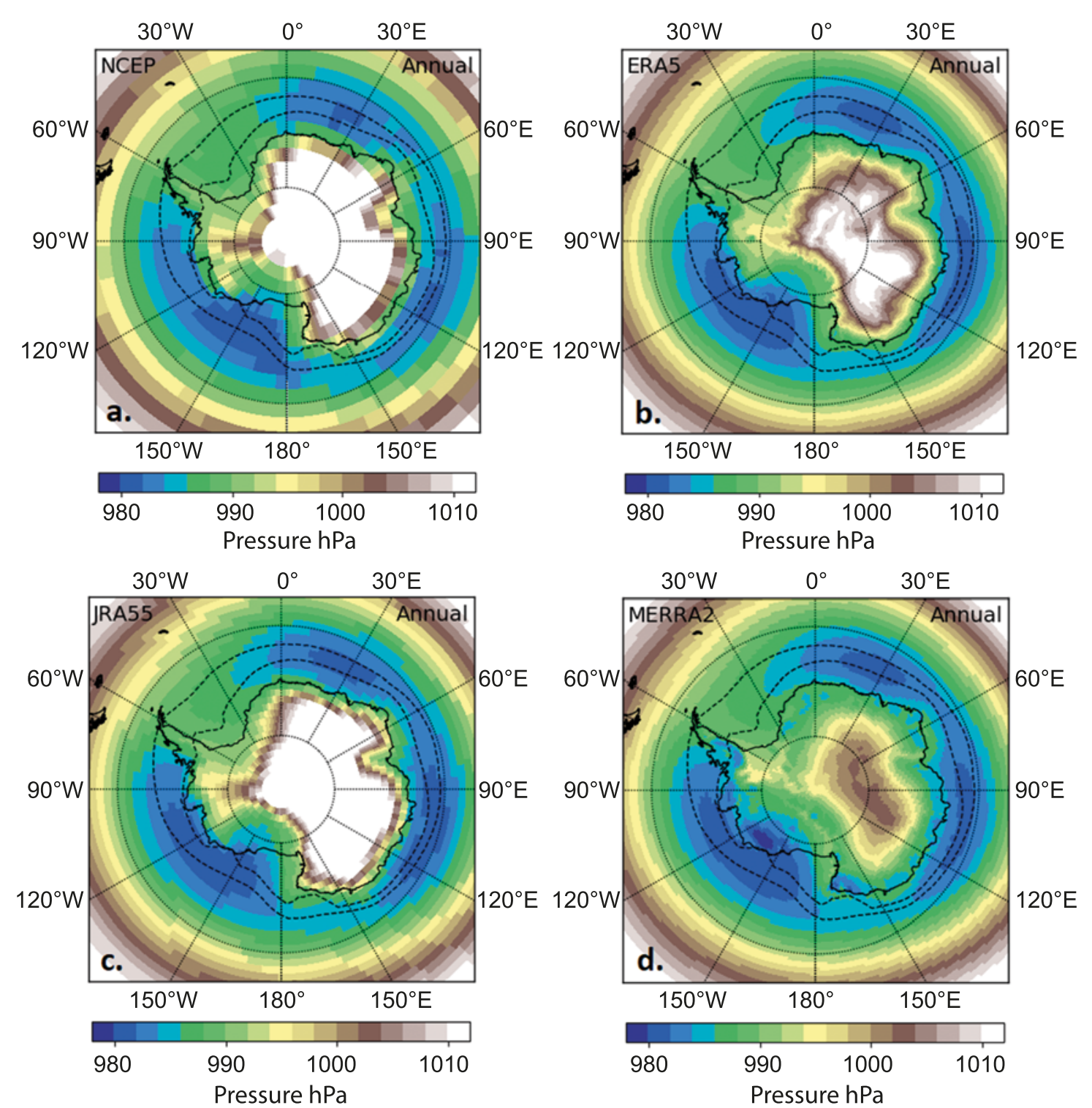

Fig. 2. Multiyear mean (1980-2020) annual sea-level pressure in Antarctic from four global reanalysis datasets, $\mathbf{a}$ - NCEP/NCAR, b - ERA5, $\mathbf{c}$ - JRA55 and d - MERRA2.

Dashed lines show the mean most southern and the most northern location of the Antarctic Circumpolar Trough (ACT) in the course of the year as determined from ERA5 reanalysis

a generally negative trend in 1980-2020 was interrupted by a period of increasing sea-level pressure in the 2000 s and in the beginning of 2010s. The observed change in the SLP trend at the break of the century as well as concurrent considerable hike in the rate of the Antarctic sea ice increase (Meehl et al., 2016), weakening of warming trends in the Antarctic Peninsula (Turner et al., 2016), weakening of the winds in the polar region (Romanova and Romanov, 2020) is evident of a broader change in the atmospheric circulation in the polar region of the Southern Hemisphere. The latter is attributable at least partially to the recovery of Antarctic stratospheric ozone, corresponding warming of the stratosphere and associated weakening of the polar vortex (e.g., Screen et al., 2018). 
ACT Annual Mean Sea-Level Pressure - Eastern Antarctica

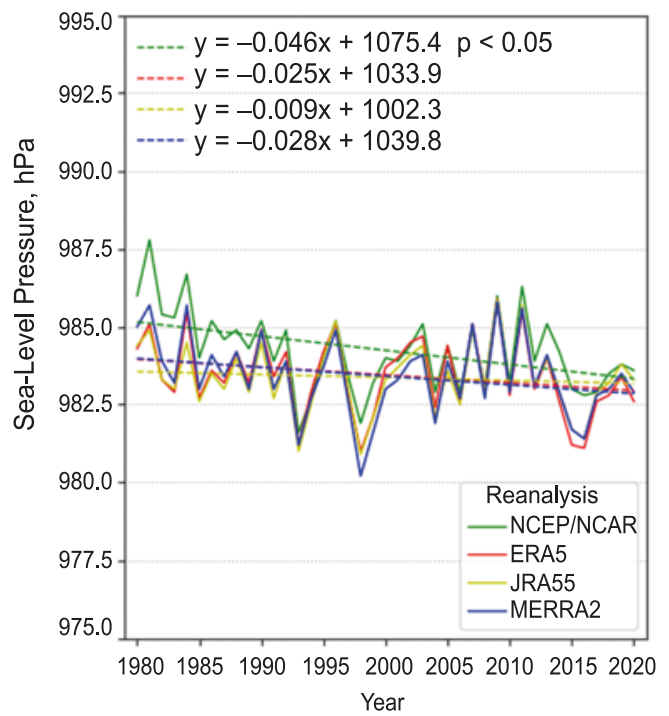

ACT Annual Mean Sea-Level Pressure - Eastern Antarctica

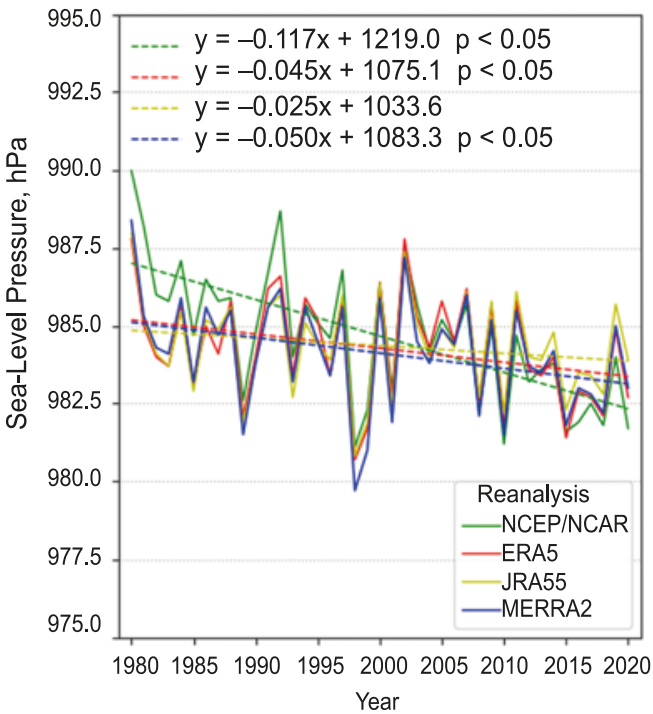

Fig. 3. Time series and trends of the annual mean sea-level pressure within the Antarctic Circumpolar Trough (ACT) region in the Eastern and Western sector of the Southern Ocean derived from four reanalysis datasets, NCEP/NCAR. ERA5, JRA55 and MERRA2.

The ACT region is defined as the area between the most southern and most northern mean seasonal location of the ACT (shown with two dashed lines in Fig. 2).

Trends have been estimated for the 1980-2020 time period

Large negative pressure trends in the Southern Hemisphere high latitudes in the NCEP/NCAR dataset were found earlier by Hines et al. (2000), who suggested that these trends may be overestimated. The overestimate was attributed to the positive bias in the sea-level pressure reanalysis data in 1950 and most of 1960s. The results of our study generally support the conclusion of an excessive negative pressure trend in the NCEP/ NCAR dataset, but, as seen from Figure 3, they indicate that the positive SLP bias remained in the NCEP/NCAR dataset for a much longer time period, at least till the end of 1980s.

Figure 4 presents the spatial distribution of the trends in the annual mean SLP derived from the four reanalysis datasets over the high-latitude region of the Southern Hemisphere. Consistent with the results of earlier studies (e.g., Schmidt and Grise, 2017; Turner et al., 2005; Turner et al., 2013; O’Connor et al., 2021), all datasets examined in our work demonstrate an overall dominance of negative trends in the annual mean SLP in Antarctica. The identified long-term decrease of the SLP is coherent with the results of studies of other weather elements over the Southern Ocean, which indicate a growing number of intense cyclones, stronger winds and larger frequency of extreme precipitation events in the last decades (Yu et al., 2020; Marshall et al., 2017). As also evident from Figure 4, there is a distinct polarity in the spatial distribution of the SLP trends with a stronger pressure decrease over time in the Western than in the Eastern sector of the Antarctic region. The strongest negative trends are attributed to the region of the Amundsen Sea Low in the South Pacific, which encompasses Bellingshausen, Amundsen and Ross Seas and adjacent coastal areas. 


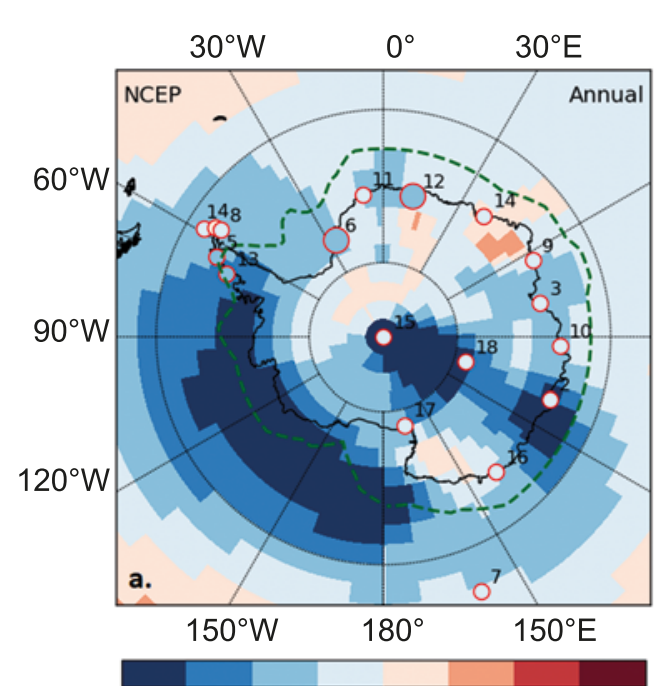

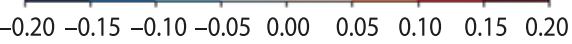
Pressure Trend, $\mathrm{hPa} /$ year

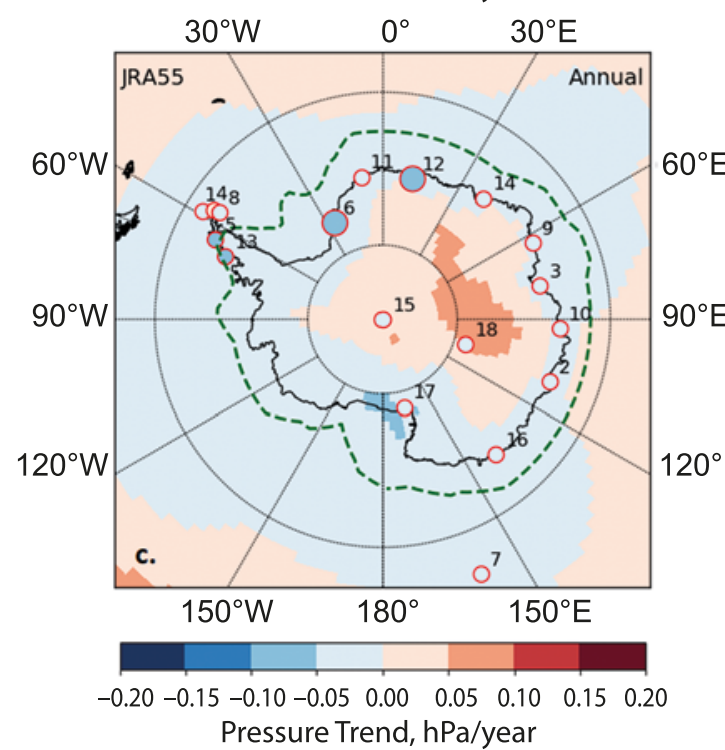

Pressure Trend, hPa/year

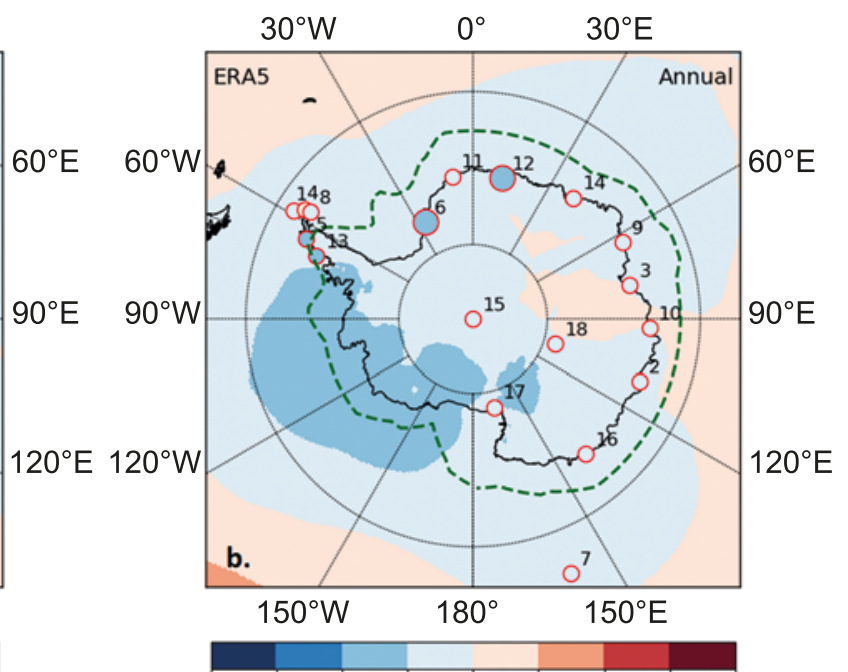


Pressure Trend, $\mathrm{hPa} /$ year

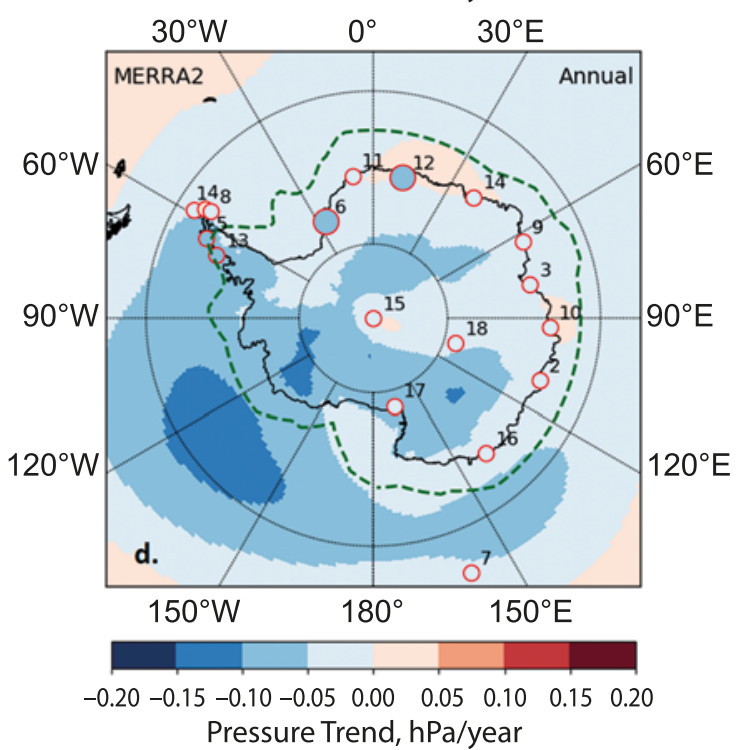

Fig. 4. Trends in the annual mean sea-level pressure derived from four reanalysis datasets (a - NCEP/NCAR, b - ERA5, c - JRA55 and d - MERRA2) over the 1980-2020 time period. Colored circles present sea-level pressure trends at the station location calculated from in situ data. Large circles indicate statistically significant trends. The list of stations with corresponding numbers is provided in Table 2. Surface-level pressure trends instead of the sea-level pressure trends are given for Amundsen-Scott (No.15) and Vostok (No.18) stations. Dashed green line indicates the annual mean position of the Antarctic Circumpolar

Trough (ACT) as per ERA5 data

While there is an overall qualitative agreement on the major spatial features of the SLP trends, their quantitative estimates vary noticeably between the reanalysis products. In particular, the NCEP/NCAR-based trend in the annual mean SLP averaged over the high-latitude portion of the Southern Hemisphere below $60^{\circ} \mathrm{S}$ amounts $-0.079 \mathrm{hPa} /$ year. This is equivalent to a pressure drop of $3.2 \mathrm{hPa}$ in the course of 41 years. Similar estimates of the area-average SLP trend in the other reanalysis 
datasets yield about 2 to over 6 times smaller values than in NCEP/NCAR. They range from $-0.047 \mathrm{hPa} /$ year (or $-1.9 \mathrm{hPa}$ change in 41 years) in MERRA2, to $-0.032 \mathrm{hPa} /$ year $(-1.3 \mathrm{hPa})$ in ERA5 and to $-0.012 \mathrm{hPa} /$ year $(-0.5 \mathrm{hPa})$ in JRA55. Even with the NCEP/ NCAR results excluded from the statistics, there is almost a four times difference between the SLP trend estimates in the remaining three datasets.

Although all reanalysis products incorporated in this work agree on the general "deepening" of the Amundsen Sea Low, as seen from Figure 4, there are noticeable discrepancies between the datasets both with respect to the particular area affected by the excessive negative pressure trends and to their magnitude. Mismatch between the products in the magnitude and even in the sign of the trends also occurs in the inner Antarctica where the annual mean SLP trends range from strongly negative, in the excess of $-0.20 \mathrm{hPa} /$ year, in NCEP/NCAR to moderately positive, within 0.05 to $0.10 \mathrm{hPA} /$ year, in JRA55.

There is a number of regional differences between our estimates of the trends in the annual mean SLP and the results of earlier studies. None of the datasets examined in our work confirms a positive pressure trend over and east of the Drake passage identified in O'Connor et al. (2021). We have also found no evidence of a marked drop of the annual-mean sea-level pressure in Cooperation Sea at around $60^{\circ} \mathrm{E}$ and in Mawson Sea at around $120^{\circ} \mathrm{E}$ reported by Schmidt and Grise (2017). Besides the specifics of individual reanalysis schemes and datasets, discrepancies in the trend estimates may be associated with shorter, ending in mid- to late- 2000 s, time series of reanalysis products utilized in the studies referred to above.

Further analysis of the SLP trends revealed their strong dependence on the time of the year. In the austral summer, i.e., in the months of December, January and February, all datasets indicate a moderate to strong long-term decrease of the pressure over much of the Southern Hemisphere high-latitudes and identify Ross Sea and the eastern part of Weddell Sea as areas of the most notable drop in the SLP (see Figure 5). At this time of the year a mismatch between the datasets is found in the inner continent where two of the products, NCEP/NCAR and JRA55, reveal mixed trends, but in the other two, ERA5 and MERRA2, the trends are persistently negative. Summer-time pressure trends averaged over the Southern Hemisphere high-latitude (below $60^{\circ} \mathrm{S}$ ) region range from $-0.065 \mathrm{hPa} /$ year to $-0.102 \mathrm{hPa} /$ year. These values are close but somewhat lower than similar estimates of Fogt et al., (2017) of -0.10 to $-0.14 \mathrm{hPa} /$ year, which were inferred from the precursor of ERA5, the ERA-Interim dataset.

In the austral fall (months of March, April and May) negative SLP trends still prevail, but their spatial pattern in the region changes. The most distinct feature of this season evident in all datasets is a remarkable pressure drop over Bellingshausen and Amundsen Seas and adjacent coastal areas corresponding to the location of the Amundsen Sea Low. However, the estimated rate of the deepening of the Amundsen Sea Low with time varies considerably between the reanalysis products ranging from over $-0.4 \mathrm{hPa} /$ year in NCEP/NCAR to within -0.14 to $-0.23 \mathrm{hPa} /$ year in the other three datasets. 
As seen from Figure 5, the winter season (months of Jun, July and August) is associated with a general weakening of negative SLP trends, a larger fraction positive trends and with an overall transition of the whole pattern of trends in the region to a mixed one. Along with these changes the overall agreement on the spatial distribution of the trends and on their magnitude between different datasets deteriorates. The latter concerns, first, the NCEP/NCAR reanalysis which attributes a strong pressure decrease to a wide area in the Southern Pacific and adjacent coastal areas as well to the inner continent with little support for these features in other datasets. There is a better correspondence on the trend spatial pattern between the other three datasets, ERA5, MERRA2 and JRA55, particularly with respect to the area of positive pressure trends in the east of Weddell Sea and two locations of weakly negative trends centered correspondingly in the Eastern and in the Western part of South Pacific.
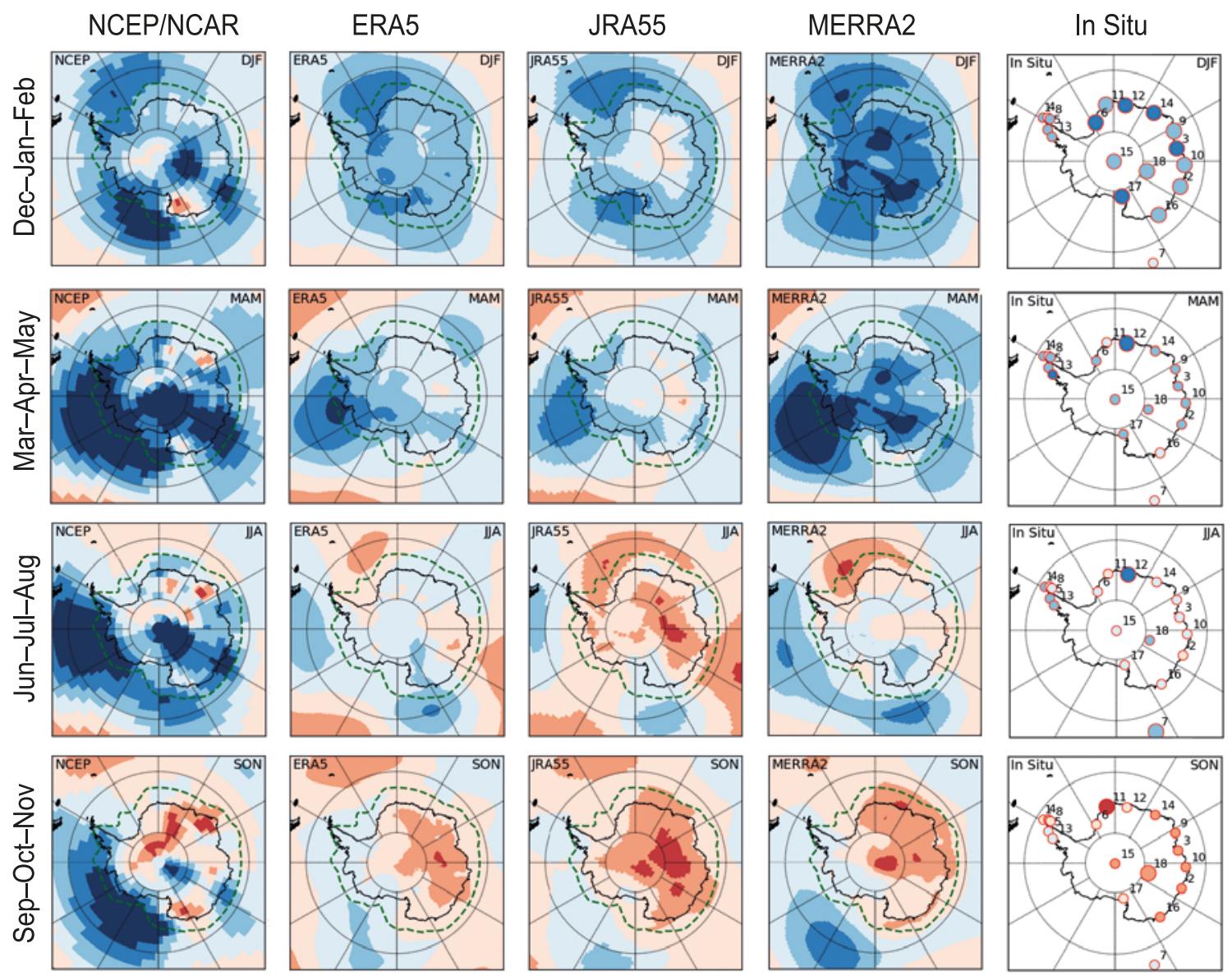

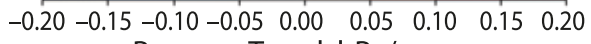

Pressure Trend, $\mathrm{hPa} /$ year

Fig. 5. Trends in the season average sea-level pressure derived from four reanalysis datasets, NCEP/NCAR, ERA5, JRA55 and MERRA2 and from in situ. In the in situ data large circles indicate trends statistically significant at 0.05 level 
The spring season (September, October, November) features a pronounced strengthening and a further expansion of the area of positive SLP trends in Antarctica. In ERA5, MERRA2 and JRA55, positive pressure trends become dominant over the Southern Hemisphere high-latitudes averaging to within 0.01 to $0.03 \mathrm{hPa} /$ year. The pressure increase with time is particularly notable in the Eastern Antarctica where it reaches $0.10-0.15 \mathrm{hPa} /$ year in all datasets. Considerable negative pressure trends in this season are found only in the Pacific sector of the Southern Ocean with larger values in NCEP/NCAR and somewhat smaller pressure decrease in MERRA2, ERA5 and JRA55.

SLP trends and patterns in Antarctica seen in individual seasons help to better understand peculiarities of the annual mean values. In particular, dominating negative trends in the annual mean SLP appear to be largely driven by strongly negative pressure trends in summer and in the fall season. Over the year these trends overweight smaller and less spatially extensive positive trends in winter and spring. Faster drop of the annual mean SLP in the Southern Pacific occurs mostly due to a strong deepening of the Amundsen Sea Low in the fall season. Discrepancies between individual reanalysis datasets on the annual mean trends are explained to a large extent by differences in the corresponding winter and spring-season trends. The latter is most clearly seen in the NCEP/NCAR product, where much stronger negative trends in winter and spring result in a similar difference between NCEP/NCAR and the other three datasets in the annual mean values.

As seen from Figures 4 and 5, seasonal peculiarities in the reanalysis-based SLP trends are generally supported by corresponding estimates from in situ instrumental data. Similar to the reanalysis products, in situ data reveal predominantly weak negative trends in the annual mean SLP, moderate to strongly negative trends of up to -0.10 to $-0.15 \mathrm{hPA} /$ year in the summer season, weakly negative trends changing to mixed trends in the fall and in winter and mostly positive SLP trends in spring. The summer season is associated with the largest fraction of statistically significant negative SLP trends in the station data, whereas in other seasons as well as in the annual means statistically significant trends are found only in the records of one or two out of 18 stations. A more detailed comparative analysis of in situ and reanalysis trends in the sea-level pressure is given in the following section of the paper.

\section{Comparison of reanalysis-based sea-level pressure trends with in situ data}

Comparison of reanalysis data with in situ observations presents a widely used approach to assess the accuracy and the performance of atmospheric reanalysis products (e.g., Yu et al., 2010). The same approach is also applicable to trends in the reanalysis variables. In this study we compared reanalysis-based trends in the SLP to corresponding trends derived from observations at Antarctic weather stations. In situ data converted to monthly mean values of SLP were acquired from the READER dataset of the British Antarctic Survey. The comparison was performed over annual mean, season mean and monthly mean values of SLP by matching in situ data to reanalysis data in the model grid 
cell encompassing the station location. Data from 18 Antarctic stations listed in Table 2 have been used.

Table 3 presents estimates of the annual mean SLP trends at the station location inferred from in situ data and from reanalysis datasets over the 1980-2020 time period. These estimates indicate a near-perfect agreement of the datasets on the sign of the annual trend value: Except of MERRA2 over Novolazarevskaya, and JRA55 over Vostok and Amundsen Scott, decreasing pressure trends inferred from the reanalysis datasets were fully supported by in situ observation data. Much larger than in situ negative trends in the NCEP/NCAR dataset provide just another evidence of a possible overestimate of the rate of the pressure drop in this dataset. Overall the cumulative statistics of matched reanalysis and in situ trends in the annual mean SLP was most favorable to the ERA5 product. As seen from Table 4, trends obtained with this dataset have the least mean bias $(0.008 \mathrm{hPa} /$ year $)$, the least root-mean square error, RMSE $(0.019 \mathrm{hPa} /$ year $)$ and the largest correlation with the station data. Close to ERA5, but a slightly larger trend bias and RMSE have been found in MERRA2 and JRA55. Although the accuracy of ERA5, MERRA2 and JRA55 trend estimates of about $0.02-0.03 \mathrm{hPa} /$ year appears high, it is of the same order of magnitude as the overall spread (or RMSD) of in situ trend values across the stations (see Table 3). This explains low, below 0.2, correlation between the reanalysis and in situ annual trend estimates at the station location.

Table 3. Annual mean SLP trends at the location of Antarctic stations from in situ data and reanalysis datasets. Statistically significant trends at $\mathrm{p}<0.05$ are shown in bold.

Surface pressure rather than the sea-level pressure data were used at Amundsen Scott and Vostok stations

\begin{tabular}{|c|c|c|c|c|c|c|}
\hline \multirow{2}{*}{$\mathrm{N}$} & \multirow{2}{*}{ Station } & \multicolumn{5}{|c|}{ Annual mean sea-level pressure trend (hPa/year) $1980-2020$} \\
\hline & & In situ & NCEP & ERA5 & JRA55 & MERRA2 \\
\hline 1 & Bellingshausen & -0.042 & -0.057 & -0.029 & -0.032 & -0.046 \\
\hline 2 & Casey & -0.020 & -0.175 & -0.006 & -0.011 & -0.031 \\
\hline 3 & Davis & -0.025 & -0.062 & -0.005 & -0.023 & -0.004 \\
\hline 4 & Esperanza & -0.005 & -0.065 & -0.031 & -0.032 & -0.044 \\
\hline 5 & Faraday & -0.048 & -0.073 & -0.036 & -0.033 & -0.057 \\
\hline 6 & Halley & -0.058 & -0.058 & -0.040 & -0.028 & -0.012 \\
\hline 7 & Macquarie & -0.046 & -0.026 & -0.024 & -0.023 & -0.033 \\
\hline 8 & Marambio & -0.037 & -0.065 & -0.032 & -0.029 & -0.045 \\
\hline 9 & Mawson & -0.025 & -0.073 & -0.022 & -0.033 & -0.023 \\
\hline 10 & Mirny & -0.011 & -0.049 & -0.002 & -0.004 & -0.001 \\
\hline 11 & Neumayer & -0.009 & -0.062 & -0.037 & -0.017 & -0.006 \\
\hline 12 & Novolazarevskaya & -0.070 & -0.030 & -0.028 & -0.018 & 0.007 \\
\hline 13 & Rothera & -0.052 & -0.115 & -0.044 & -0.036 & -0.059 \\
\hline 14 & Syowa & -0.034 & -0.002 & -0.029 & -0.008 & -0.007 \\
\hline 15 & Amundsen Scott & -0.014 & -0.151 & -0.029 & 0.026 & -0.013 \\
\hline 16 & Dumont Durville & -0.014 & -0.053 & -0.028 & -0.019 & -0.024 \\
\hline 17 & Scott Base & -0.043 & -0.065 & -0.049 & -0.051 & -0.060 \\
\hline 18 & Vostok & -0.021 & -0.137 & -0.018 & 0.056 & -0.042 \\
\hline \multicolumn{7}{|c|}{ Aggregated sea-level pressure trend statistics } \\
\hline \multicolumn{2}{|c|}{ Mean (hPa/year) } & -0.034 & -0.065 & -0.027 & -0.024 & -0.025 \\
\hline \multicolumn{2}{|c|}{ RMSD (hPa/Year) } & 0.019 & 0.041 & 0.013 & 0.010 & 0.022 \\
\hline
\end{tabular}


Romanov P. Yu., Romanova N.A.

Table 4. Performance metrics of reanalysis datasets for the annual mean SLP trend aggregated over all selected Antarctic weather stations

\begin{tabular}{|l|c|c|c|c|}
\hline \multirow{2}{*}{\multicolumn{1}{|c|}{ Performance Metric }} & \multicolumn{4}{|c|}{ Reanalysis datasets } \\
\cline { 2 - 5 } & NCEP & ERA5 & JRA55 & MERRA2 \\
\hline Mean bias (hPa/year) & -0.031 & 0.008 & 0.011 & 0.010 \\
\hline RMSE (hPa/year) & 0.056 & 0.019 & 0.022 & 0.030 \\
\hline Correlation & -0.104 & 0.202 & 0.121 & 0.055 \\
\hline
\end{tabular}
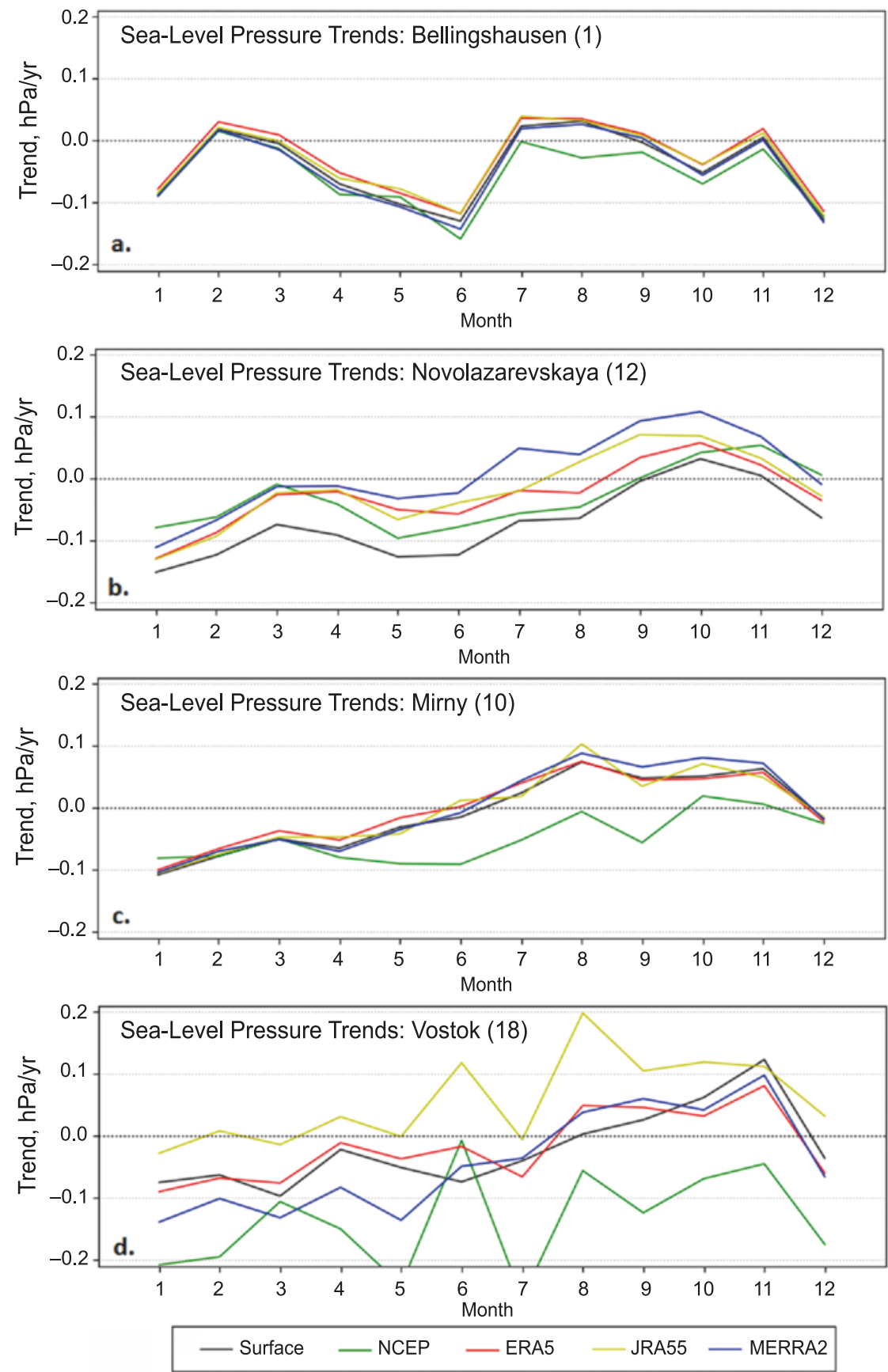

Fig. 6. Monthly sea-level pressure trends at station locations from in situ data and reanalysis datasets, a - Bellingshausen, b- Novolazarevskaya, c-Mirny, $\mathbf{d}$ - Vostok 
Figure 6 presents in situ and reanalysis-based monthly SLP trends at four stations located in different parts of the Antarctic continent. The results demonstrate a complex regional and seasonal pattern of the trends and an overall good skill of reanalysis datasets in reproducing the trends observed on the ground. At the Bellingshausen station located in the Antarctic Peninsula region the strongest negative trends are associated with the two seasons of the year (Figure 6a). One of the peaks occurs in mid-summer (December and January) and the other falls on the mid-fall to early winter time period (April, May and June). East of the Antarctic Peninsula, in the Atlantic Ocean sector of Antarctica, the minimum in April-June weakens (see Figure 6b for the Novolazarevskaya station) and completely fades out in the Indian Ocean sector (Figure $6 \mathrm{c}$ for the Mirny station). The seasonal pattern of the SLP trends with a single minimum in summer is also seen in the inner Antarctica (see Figure 6d for the Vostok station). However, in this latter case only ERA5 and, to a certain extent, MERRA2 appear to adequately reproduce this pattern. Larger inconsistencies in the trend values between in situ observations and reanalysis datasets at inner Antarctica locations may be associated with the use of the surface pressure data instead of SLP in the station-based trend estimates and with large uncertainties in the reanalysis-based SLP estimates due to the high surface elevation.

When aggregated over all Antarctic stations included in the study, the performance statistics of the four reanalysis datasets with respect to the trends in the monthly mean SLP reveals a distinct seasonal pattern with an agreement to in situ data improving in the austral summer months and decreasing in winter. Similar to the earlier results, NCEP/NCAR stands out by its grossly overestimated negative trend (hence, a strong negative bias) as compared to the station data, larger RMSE and smaller correlation (see Figure 7). The remaining three reanalysis datasets demonstrate closer performance levels in the course of the year. However, the overall best performance with the smallest, below $0.03 \mathrm{hPa} /$ year, RMSE and the largest correlation to in situ data is attained with the ERA5 product.
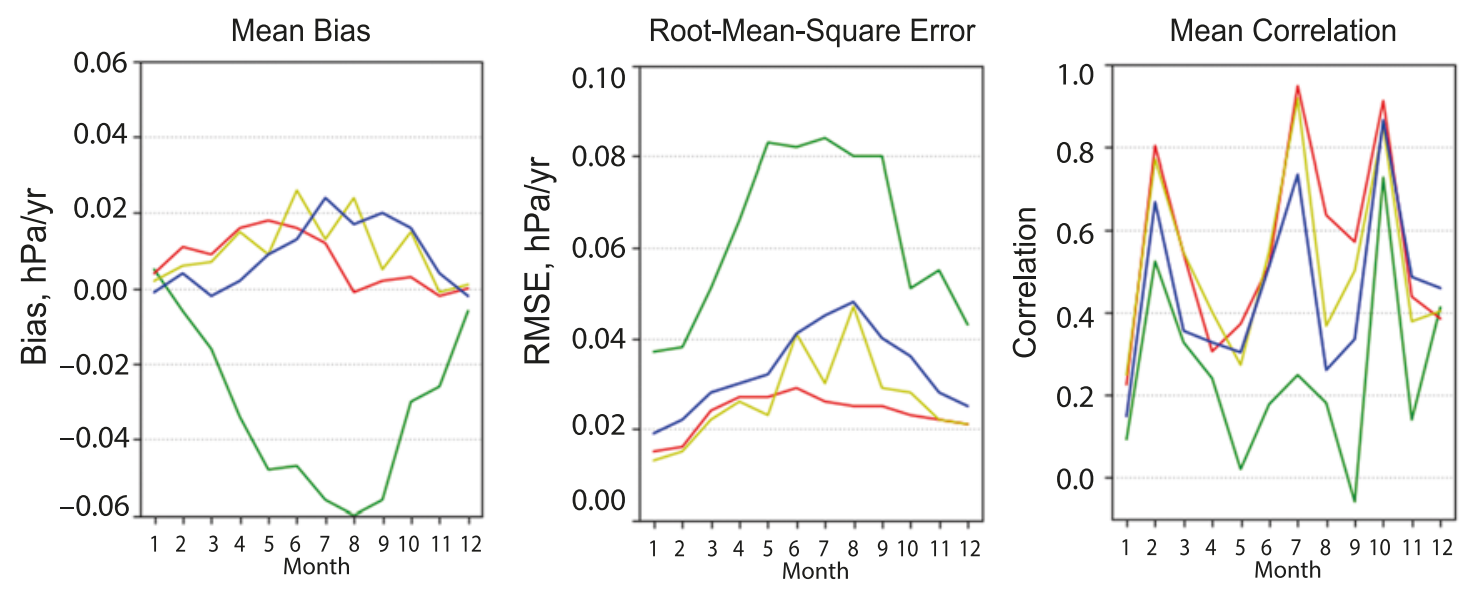

- NCEP — ERA5 — JRA55 -MERRA2

Figure. 7. Mean bias, root-mean-square error and correlation of monthly mean SLP trends in the reanalysis datasets vs corresponding trends in in situ data 


\section{Discussion and Conclusion}

In this study we have used the most up to date data records from four state of the art reanalysis datasets to infer, evaluate and compare long-term trends in the sea-level pressure over high latitudes of the Southern Hemisphere. The analysis incorporated products generated with NCEP/NCAR, ERA5, MERAA2 and JRA55 reanalysis schemes over the 41-year time period, from 1980 to 2020 . Trends in the SLP from reanalysis datasets were compared to corresponding trends derived from in situ observations at Antarctic weather station data to assess the validity and the accuracy of the model-based estimates. Annual, seasonal and monthly trends in the SLP have been examined.

The sea-level pressure trends obtained in this study showed a good qualitative agreement to the results of earlier studies of the trends involving various reanalysis datasets, climate model output and in situ data. This concerns in particular, the findings of predominantly decreasing trends in the annual mean SLP over the Southern Ocean and Antarctic continent, of the strongest negative pressure trends in the summer season and of a pronounced "deepening" of the Amundsen Sea Low. The typical range of estimated trends in the annual mean SLP in Antarctica was -0.01 to $-0.15 \mathrm{hPa} /$ year with maximum values peaking at over $-0.20 \mathrm{hPa} /$ year.

Consistent with the results of earlier studies, large, and apparently excessive, negative SLP trends were identified in the NCEP/NCAR dataset. Over the 1980-2020 time period annual mean SLP trends based on the NCEP/NCAR data were 2-3 times larger than trends inferred from the other three datasets, ERA5, MERRA2 and JRA55. Similar discrepancies were also found between the NCEP/NCAR SLP trends and trends estimated from instrumental observations at Antarctic weather stations.

Our analysis revealed a number of other common peculiarities in the spatial and seasonal distribution of the SLP trends derived from different datasets. All reanalysis datasets included in this study showed a marked continental-scale polarity in the annual mean SLP trends: The mean magnitude of negative trends derived with the same dataset was about two times larger in the Western than in the Eastern sector of Antarctica and the Southern Ocean. All datasets were found to agree on a strong seasonality in the SLP trends in Antarctica. We have shown that mostly negative SLP trends in the austral summer and in fall turn to mixed and to mostly positive trends correspondingly in summer and in spring. The largest positive pressure trends in spring reaching $0.1-0.15 \mathrm{hPa} /$ year were identified in the continental Eastern Antarctica. Despite the changing sign of the pressure trends in the course of the year, positive SLP trends in winter and in spring season were generally smaller than negative trends in summer and fall. As a result, negative SLP trends prevailed in the annual means.

Although there are certain distinct similarities in the spatial and seasonal patterns of the SLP trends derived from different datasets, the magnitude of the trends may vary. In particular, the estimated annual mean SLP trends averaged across the entire Antarctica and Southern Ocean change about 4 times between the three datasets, ERA5, MERRA2 and JRA55 ranging from $-0.012 \mathrm{hPa} /$ year to $-0.047 \mathrm{hPa} /$ year. The spread 
between estimates further increases when overestimated negative trends in the NCEP/ NCAR are also incorporated in the statistics. Large variation of the trends inferred from different dataset is indicative of a considerable uncertainty associated with the estimated SLP trend values.

Comparison with available in situ observations at weather stations in Antarctica confirmed a gross overestimate of negative SLP trends in the NCEP/NCAR dataset and a generally comparable performance of ERA5, MERRA2 and JRA55 reanalysis products. The latter three datasets agree on the trend magnitude in the annual and on the monthly mean SLP with in situ-based data to within $0.02-0.04 \mathrm{hPa} /$ year. This accuracy is hardly sufficient to capture variation in the annual mean trend value across the station locations which is about the same order of magnitude. It is, however, adequate to properly reproduce a much larger, up to and exceeding $0.2 \mathrm{hPa} /$ year, spatial variation of the annual mean trends over a broader Southern Hemisphere high-latitude domain and the seasonal variation of the SLP trends.

Although the three reanalysis datasets, MERRA2, JRA55 and ERA5, demonstrated a close match to SLP trends estimated from in situ data, the best agreement was found in ERA5. Higher spatial resolution of ERA5 as compared to all other datasets and, correspondingly its ability to resolve and reproduce smaller scale peculiarities in the sea-level pressure spatial distribution appears as at least one of the factors that contribute to the better performance of this product.

Comparison with the station data is commonly used to assess the accuracy of reanalysis datasets. It should be remembered however that in the case of the sea-level pressure data in Antarctica the validity of this approach is somewhat limited. Surface pressure observations at Antarctic weather stations are incorporated in all reanalysis schemes, consequently, the two datasets and, hence the corresponding trend estimates are not fully independent per se. Furthermore, except of Vostok and Amundsen Scott, staffed Antarctic weather stations with long-term atmospheric pressure records are confined to the coastal area. In the last two decades efforts have been made to improve the in situ data coverage of the Antarctic continent by installing automated weather stations (e.g., Lazzara et al., 2018). However, maintenance of these stations is challenging and time is needed for the data records to reach the duration sufficient for climatological use. Therefore, over the open ocean and over vast areas of inner Antarctica the agreement between reanalysis datasets remains the only viable criterion to judge the validity of the derived SLP trends.

Acknowledgements: The authors would like to thank three anonymous reviewers for critically reading the paper. Comments and suggestions of all reviewers helped to substantially improve and clarify the manuscript. 


\section{References}

Bromwich, D.H., J.P. Nicolas, A.J. Monaghan, M.A. Lazzara, L.M. Keller, G.A. Weidner, and A.B. Wilson, 2014: Correction: Corrigendum: Central West Antarctica among the most rapidly warming regions on Earth. Nature Geosci., 7, p. 76.

Carril, A.F., C.G. Menendez, and A. Navarra, 2005: Climate response associated with the Southern Annular Mode in the surroundings of Antarctic Peninsula: A multimodel ensemble analysis. Geophys. Res. Lett., 32, L16713, https://doi.org/10.1029/2005GL023581.

Cook, A.J., P.R. Holland, M.P. Meredith, T. Murray, A. Luckman and D.G. Vaughan, 2016: Ocean forcing of glacier retreat in the western Antarctic Peninsula, Science, 353, $283-286$.

Gelaro, R., W. McCarty, M.J. Suárez, R. Todling, A. Molod, L. Takacs, C.A. Randles, A. Darmenov, M.G. Bosilovich, R. Reichle, K. Wargan, L. Coy, R. Cullather, C. Draper, S. Akella, V. Buchard, A. Conaty, A.M. da Silva, W. Gu, G.-K. Kim, R. Koster, R. Lucchesi, D. Merkova, J.E. Nielsen, G. Partyka, S. Pawson, W. Putman, M. Rienecker, S.D. Schubert, M. Sienkiewicz, and B. Zhao, 2017: The ModernEra Retrospective Analysis for Research and Applications, Version 2 (MERRA2), J. Climate, 30, 5419-5454.

Hersbach, H., P. de Rosnay, B. Bell, D. Schepers, A. Simmons, C. Soci, S. Abdalla, M. AlonsoBalmaseda, G. Balsamo, P. Bechtold, P. Berrisford, J.-R. Bidlot, E. de Boisséson, M. Bonavita, P. Browne, R. Buizza, P. Dahlgren, D. Dee, R. Dragani, M. Diamantakis, J. Flemming, R.L. Fogt, C.A. Goergens, J.M. Jones, D.P. Schneider, J.P. Nicolas, D.H. Bromwich, and H.E. Dusselier, 2017: A twentieth century perspective on summer Antarctic pressure change and variability and contributions from tropical SSTs and ozone depletion, Geophys. Res. Lett., 44, 9918-9927, https://doi.org/10.1002/2017GL075079.

Fogt, R.L. and G.J. Marshall, 2020: The Southern Annular Mode: Variability, trends, and climate impacts across the Southern Hemisphere. WIREs Climate Change., 11, e652, https://doi. org/10.1002/wcc. 652 .

Forbes, R., A.J. Geer, T. Haiden, E. Hólm, L. Haimberger, R. Hogan, A. Horányi, M. Janiskova, P. Laloyaux, P. Lopez, J. Munoz-Sabater, C. Peubey, R. Radu, D. Richardson, J.-N. Thépaut, F. Vitart, X. Yang, E. Zsótér, and H. Zuo, 2018: Operational global reanalysis: progress, future directions and synergies with NWP, ERA Report Series, 27, $63 \mathrm{p}$.

Ho, C.-H., J.-H. Kim, H.-S. Kim, C.-H. Sui, and D.-Y. Gong, 2005: Possible influence of the Antarctic Oscillation on tropical cyclone activity in the western North Pacific, J. Geophys. Res., 110, D19104, https://doi.org/10.1029/2005JD005766.

Hodges, K.I., R.W. Lee and L. Bengtsson, 2001: A comparison of extratropical cyclones in recent reanalyses ERA-interim, NASA MERRA, NCEP CFSR, and JRA-25. Journal of Climate, 24, 4888-4906, https://doi.org/10.1175/2011JCLI4097.1.

Kalnay, E., M. Kanamitsu, R. Kistler, W. Collins, D. Deaven, L. Gandin, M. Iredell, S. Saha, G. White, J. Woollen, Y. Zhu, M. Chelliah, W. Ebisuzaki, W. Higgins, J. Janowiak, K.C. Mo, C. Ropelewski, J. Wang, A. Leetmaa, R. Reynolds, R. Jenne, D. Joseph, 1996: The NCEP/NCAR 40-year reanalysis project. Bulletin of American Meteorological Society, 77, 437-470.

Kobayashi, S., Y. Ota, Y. Harada, A. Ebita, M. Moriya, H. Onoda, K. Onogi, H. Kamahori, C. Kobayashi, H. Endo, K. Miyaoka, and K. Takahashi, 2015: The JRA-55 Reanalysis: General Specifications and Basic Characteristics. J. Meteorol. Soc. Japan, 93, $5-48$.

Lazzara, M.A., J.G. Powers, C.A. Costanza, D.H. Bromwich, S. Carpentier and S. Colwell, 2018: The 12th Workshop on Antarctic Meteorology and Climate. Adv. Atmos. Sci., 35, 753-756. 
Lefebvre, W., H. Goosse, R. Timmermann, and T. Fichefet, 2004: Influence of the Southern Annular Mode on the sea ice-ocean system. J. Geophys. Res., 109, C09005, https://doi. org/10.1029/2004JC002403.

Lovenduski, N.S. and N. Gruber, 2005: Impact of the Southern Annular Mode on Southern Ocean circulation and biology. Geophys. Res. Lett., 32, L11603, https://doi. org/10.1029/2005GL022727.

Marshall, G.J., A. Orr, N.P.M. van Lipzig, and J.C. King, 2006: The impact of a changing Southern Hemisphere Annular Mode on Antarctic Peninsula summer temperatures. Journal of Climate, 19(20), 5388- 5404.

Marshall, G.J., D.W.J. Thompson, and M.R. van den Broeke, 2017: The signature of Southern Hemisphere atmospheric circulation patterns in Antarctic precipitation. Geophysical Research Letters, 44, 11,580-11,589, https://doi.org/10.1002/2017GL075998.

Meehl, G., J. Arblaster, C. Bitz, C.T.Y. Chung and H. Teng, 2016: Antarctic sea-ice expansion between 2000 and 2014 driven by tropical Pacific decadal climate variability. Nature Geoscience, 9, 590-595, https://doi.org/10.1038/ngeo275.1.

Menezes, V.V., A.M. McDonald, and C. Schatzman, 2017: Accelerated freshening of Antarctic bottom water over the last decade in the Southern Indian Ocean. Science Advances, 3(1), e1601426, https://doi.org/10.1126/sciadv.1601426.

O'Connor, G., E. Steig and G. Hakim, 2021: Southern Ocean surface pressure and winds during the 20th century from proxy-data assimilation. Research Square, https://doi.org/10.21203/ rs.3.rs-151209/v1.

Romanova, N.A. and P.Yu. Romanov, 2020: Antarctic wind intensification as inferred from the NCEP/NCAR reanalysis data. Journal of Oceanological Research, 48(3), 96-108.

Schmidt, D.F., and K.M. Grise, 2017: The response of local precipitation and sea level pressure to Hadley cell expansion. Geophysical Research Letters, 44, 10,573-10,582, https://doi. org/10.1002/2017GL075380.

Screen, J.A., T.J. Bracegirdle, and I. Simmonds, 2018: Polar Climate Change as Manifest in Atmospheric Circulation. Current Climate Change Reports, 4, 383-395.

Smith, K.E., R.B. Aronson, B.V. Steffel, M.O. Amsler, S. Thatje, H. Singh, J. Anderson, C.J. Brothers, A. Brown, D.S. Ellis, J.N. Havenhand, W.R. James, P.-O. Moksnes, A.W. Randolph, T. Sayre-McCord, and J.B. McClintock, 2017: Climate change and the threat of novel marine predators in Antarctica. Ecosphere, 8(11), e02017, https://doi.org/10.1002/ ecs2.2017.

Thompson, D.W.J. and S. Solomon, 2002: Interpretation of recent Southern Hemisphere climate change. Science, 296, 895-899.

Turner, J., S.R. Colwell, G.J. Marshall, T.A. Lachlan-Cope, A.M. Carleton, P.D. Jones, V. Lagun, P.A. Reid and S. Iagovkina, 2005: Antarctic climate change during the last 50 years. Int. J. Climatol., 25, 279-294, https://doi.org/10.1002/joc.1130.

Turner, J., T. Maksym, T. Phillips, G.J. Marshall, and M.P. Meredith, 2013: The impact of changes in sea ice advance on the large winter warming on the western Antarctic Peninsula. Int. J. Climatol., 33, 852-861, https://doi.org/10.1002/joc.3474.

Turner, J., T. Phillips, J.S. Hosking, G.J. Marshall, and A. Orr, 2013: The Amundsen Sea low. Int. J. Climatol., 33, 1818-1829, https://doi.org/10.1002/joc.3558.

Turner, J., H. Lu, I. White, J.C. King, T. Phillips, J.S. Hosking, T.J. Bracegirdle, G.J. Marshall, R. Mulvaney and P. Deb, 2016: Absence of 21st century warming on Antarctic Peninsula consistent with natural variability. Nature, 535, 411-415.

Uotila, P., T. Vihma, A.B. Pezza, I. Simmonds, K. Keay, and A.H. Lynch, 2011: Relationships between Antarctic cyclones and surface conditions as derived from high-resolution 
numerical weather prediction data, J. Geophys. Res., 116, D07109, https://doi. org/10.1029/2010JD015358.

Wei, L. and T. Qin, 2016: Characteristics of cyclone climatology and variability in the Southern Ocean. Acta Oceanol. Sin., 35, 59-67.

Yu, L., Z. Zhang, M. Zhou, S. Zhong, D. Lenschow, H. Hsu, H. Wu and B. Sun, 2010: Validation of ECMWF and NCEP-NCAR reanalysis data in Antarctica. Adv. Atmos. Sci., 27, 11511168.

Yu, L., S. Zhong, and B. Sun, 2020: The Climatology and Trend of Surface Wind Speed over Antarctica and the Southern Ocean and the Implication to Wind Energy Application. Atmosphere, 11(1), 108, https://doi.org/10.3390/atmos11010108.

\title{
ТРЕНДЫ ДАВЛЕНИЯ НА УРОВНЕ МОРЯ В ЮЖНОМ ОКЕАНЕ И АНТАРКТИКЕ ПО РЕЗУЛЬТАТАМ РЕАНАЛИЗА И НАЗЕМНЫМ ДАННЫМ
}

\author{
Романов П.Ю.', Романова Н.А. ${ }^{2}$ \\ ${ }^{1}$ NOAA-CREST, City University of New York, New York, NY 10031, USA \\ e-mail:peter.romanov@noaa.gov \\ ${ }^{2}$ Институт океанологии им. П.П. Ширшова РАН, \\ Россия, 117997, Москва, Нахимовский проспект, 36, \\ e-mail:romanova@ocean.ru
}

Статья поступила в редакцию 22.08.2021, одобрена к печати 15.12.2021.

\begin{abstract}
Тренды среднего атмосферного давления на уровне моря в Антарктике и Южном океане за песледние четыре десятилетия (1980-2020 гг.) были изучены с использованием наземных наблюдений и данных реанализа. Анализ включал временные ряды среднемесячных значений давления на уровне моря, полученных из четырех наборов данных реанализа, NCEP/NCAR, ERA5, JRA55, MERRA2, а также из приземных наблюдений, полученных из базы Справочных антарктических данных для исследований окружающей среды (Reference Antarctic Data for Environmental Research, READER). C помощью этих данных мы оценили величину трендов, описали их сезонные особенности и изменчивость в высокоширотном регионе Южного полушария. Результаты анализа показали преобладание тенденций к снижению среднегодового давления на уровне моря в Антарктике. Более сильные отрицательные тенденции были обнаружены в Западной Антарктике с наиболее выраженным падением давления в тихоокеанском секторе Южного океана. Снижение среднегодового давления в Антарктиде было обусловлено, главным образом, сильными отрицательными трендами давления в летнем и осеннем сезоне южного полушария, тогда как зимой и весной тренды были, соответственно, разнонаправленными и в основном положительными. Сравнение многолетних рядов данных реанализа давления на уровне моря с наземными наблюдениями на антарктических станциях выявило значительную переоценку отрицательных трендов давления в наборе данных NCEP/NCAR. Среди четырех исследованных наборов данных реанализа ERA5 показал наилучшее соответствие со станционными данными в отношении среднегодовых и среднемесячных значений тренда давления.
\end{abstract}

Ключевые слова: реанализ, Антарктический регион, среднее давление на уровне моря, тренды, натурные наблюдения 
Благодарности. Авторы хотели бы поблагодарить трех анонимных рецензентов за прочтение статьи. Комментарии и предложения всех рецензентов помогли существенно улучшить и уточнить рукопись.

\section{Литература}

Bromwich D.H., Nicolas J.P., Monaghan A.J., Lazzara M.A., Keller L.M., Weidner G.A., and Wilson A.B. Correction: Corrigendum: Central West Antarctica among the most rapidly warming regions on Earth // Nature Geosci. 2014. Vol. 7. P. 76.

Carril A.F., Menendez C.G., and Navarra A. Climate response associated with the Southern Annular Mode in the surroundings of Antarctic Peninsula: A multimodel ensemble analysis

// Geophys. Res. Lett. 2005. Vol. 32. L16713. https://doi.org/10.1029/2005GL023581.

Cook A.J., Holland P.R., Meredith M.P., Murray T., Luckman A. and Vaughan D.G. Ocean forcing of glacier retreat in the western Antarctic Peninsula // Science. 2016. Vol. 353. P. 283-286.

Gelaro R., McCarty W., Suárez M.J., Todling R., Molod A., Takacs L., Randles C.A., Darmenov A., Bosilovich M.G., Reichle R., Wargan K., Coy L., Cullather R., Draper C., Akella S., Buchard V., Conaty A., da Silva A.M., Gu W., Kim G.-K., Koster R., Lucchesi R., Merkova D., Nielsen J. E., Partyka G., Pawson S., Putman W., Rienecker M., Schubert S.D., Sienkiewicz M., and Zhao B. The Modern-Era Retrospective Analysis for Research and Applications, Version 2 (MERRA2) // J. Climate. 2017. Vol. 30. P. 5419-5454.

Hersbach H., de Rosnay P., Bell B., Schepers D., Simmons A., Soci C., Abdalla S., AlonsoBalmaseda M., Balsamo G., Bechtold P., Berrisford P., Bidlot J.-R., de Boisséson E., Bonavita M., Browne P., Buizza R., Dahlgren P., Dee D., Dragani R., Diamantakis M., Flemming J., Fogt R.L., Goergens C. A., Jones J.M., Schneider D.P., Nicolas J.P., Bromwich D.H., and Dusselier H.E. A twentieth century perspective on summer Antarctic pressure change and variability and contributions from tropical SSTs and ozone depletion // Geophys. Res. Lett. 2017. Vol. 44. P. 9918-9927. https://doi. org/10.1002/2017GL075079.

Fogt R.L. and Marshall G.J. The Southern Annular Mode: Variability, trends, and climate impacts across the Southern Hemisphere // WIREs Climate Change. 2020. Vol. 11. e652. https:// doi.org/10.1002/wcc.652.

Forbes R., Geer A.J., Haiden T., Hólm E., Haimberger L., Hogan R., Horányi A., Janiskova M., Laloyaux P., Lopez P., Munoz-Sabater J., Peubey C., Radu R., Richardson D., Thépaut J.-N., Vitart F., Yang X., Zsótér E., and Zuo H. Operational global reanalysis: progress, future directions and synergies with NWP // ERA Report Series. 2018. Vol. 27. 63 p.

Ho C.-H., Kim J.-H., Kim H.-S., Sui C.-H. and Gong D.-Y. Possible influence of the Antarctic Oscillation on tropical cyclone activity in the western North Pacific// J. Geophys. Res. 2005. Vol. 110. D19104. https://doi.org/10.1029/2005JD005766.

Hodges K.I., Lee R.W. and Bengtsson L. A comparison of extratropical cyclones in recent reanalyses ERA-interim, NASA MERRA, NCEP CFSR, and JRA-25 // J. of Climate. 2001. Vol. 24. P. 4888-4906. https://doi.org/10.1175/2011JCLI4097.1.

Kalnay E., Kanamitsu M., Kistler R., Collins W., Deaven D., Gandin L., Iredell M., Saha S., White G., Woollen J., Zhu Y., Chelliah M., Ebisuzaki W., Higgins W., Janowiak J., Mo K. C., Ropelewski C., Wang J., Leetmaa A., Reynolds R., Jenne R., Joseph D. The NCEP/NCAR 
40-year reanalysis project // Bulletin of American Meteorological Society. 1996. Vol. 77. P. 437-470.

Kobayashi S., Ota Y., Harada Y., Ebita A., Moriya M., Onoda H., Onogi K., Kamahori H., Kobayashi C., Endo H., Miyaoka K., and Takahashi K. The JRA-55 Reanalysis: General Specifications and Basic Characteristics // J. Meteorol. Soc. Japan. 2015. Vol. 93. P. 5-48.

Lazzara M.A., Powers J.G., Costanza C.A., Bromwich D.H., Carpentier S. and Colwell S. The 12th Workshop on Antarctic Meteorology and Climate // Adv. Atmos. Sci. 2018. Vol. 35. P. 753-756.

Lefebvre W., Goosse H., Timmermann R., and Fichefet T. Influence of the Southern Annular Mode on the sea ice-ocean system // J. Geophys. Res. 2004. Vol. 109. C09005. https://doi. org/10.1029/2004JC002403.

Lovenduski N.S., and Gruber N. Impact of the Southern Annular Mode on Southern Ocean circulation and biology // Geophys. Res. Lett. 2005. Vol. 32. L11603. https://doi. org/10.1029/2005GL022727.

Marshall G.J., Orr A., van Lipzig N.P.M. and King $J$ C. The impact of a changing Southern Hemisphere Annular Mode on Antarctic Peninsula summer temperatures // J. Climate. 2006. Vol. 19(20). P. 5388-5404.

Marshall G.J., Thompson D.W.J., and van den Broeke M.R. The signature of Southern Hemisphere atmospheric circulation patterns in Antarctic precipitation // Geophysical Research Letters. 2017. Vol. 44. P. 11,580-11,589. https://doi.org/10.1002/2017GL075998.

Meehl G., Arblaster J., Bitz C., Chung C.T.Y., and Teng H. Antarctic sea-ice expansion between 2000 and 2014 driven by tropical Pacific decadal climate variability // Nature Geoscience. 2016. Vol. 9. P. 590-595 (2016). https://doi.org/10.1038/ngeo2751.

Menezes V.V., McDonald A.M. and Schatzman C. Accelerated freshening of Antarctic bottom water over the last decade in the Southern Indian Ocean // Science Advances. 2017. Vol. 3(1). e1601426. https://doi.org/10.1126/sciadv.1601426.

O'Connor G., Steig E. and Hakim G. Southern Ocean surface pressure and winds during the 20th century from proxy-data assimilation // Research Square. 2021. https://doi.org/10.21203/ rs.3.rs-151209/v1.

Romanova N.A. and Romanov P.Yu. Antarctic wind intensification as inferred from the NCEP/NCAR reanalysis data // Journal of Oceanological Research. 2020. Vol. 48(3). P. $96-108$.

Schmidt D.F., and Grise K.M. The response of local precipitation and sea level pressure to Hadley cell expansion // Geophysical Research Letters. 2017. Vol. 44. P. 10,573-10,582. https:// doi.org/10.1002/2017GL075380.

Screen J.A., Bracegirdle T.J. and Simmonds I. Polar Climate Change as Manifest in Atmospheric Circulation // Current Climate Change Reports. 2018. Vol. 4. P. 383-395.

Smith K.E., Aronson R.B., Steffel B.V., Amsler M.O., Thatje S., Singh H., Anderson J., Brothers C.J., Brown A., Ellis D.S., Havenhand J.N., James W.R., Moksnes P.-O., Randolph A.W., Sayre-McCord T., and McClintock J.B. Climate change and the threat of novel marine predators in Antarctica // Ecosphere. 2017. Vol. 8(11). e02017. https://doi. org/10.1002/ecs2.2017.

Thompson D.W J. and Solomon S. Interpretation of recent Southern Hemisphere climate change // Science. 2002. Vol. 296. P. 895-899.

Turner J., Colwell S.R., Marshall G.J., Lachlan-Cope T.A., Carleton A.M., Jones P.D., Lagun V., Reid P.A. and Iagovkina S. Antarctic climate change during the last 50 years // Int. J. Climatol. 2005. Vol. 25. P. 279-294. https://doi.org/10.1002/joc.1130. 
Turner J., Maksym T., Phillips T., Marshall G.J. and Meredith M.P. The impact of changes in sea ice advance on the large winter warming on the western Antarctic Peninsula // Int. J. Climatol. 2013. Vol. 33. P. 852-861. https://doi.org/10.1002/joc.3474.

Turner J., Phillips T., Hosking J.S., Marshall G.J. and Orr A. The Amundsen Sea low // Int. J. Climatol. 2013. Vol. 33. P. 1818-1829. https://doi.org/10.1002/joc.3558.

Turner J., Lu H., White I., King J.C., Phillips T., Hosking J.S., Bracegirdle T.J., Marshall G.J., Mulvaney R. and Deb P. Absence of 21st century warming on Antarctic Peninsula consistent with natural variability // Nature. 2016. Vol. 535. P. 411-415.

Uotila P., Vihma T., Pezza A.B., Simmonds I., Keay K., and Lynch A.H. Relationships between Antarctic cyclones and surface conditions as derived from high-resolution numerical weather prediction data // J. Geophys. Res. 2011. Vol. 116. D07109. https://doi. org/10.1029/2010JD015358.

Wei L. and Qin T. Characteristics of cyclone climatology and variability in the Southern Ocean // Acta Oceanol. Sin. 2016. Vol. 35. P. 59-67.

Yu L., Zhang Z., Zhou M., Zhong S., Lenschow D., Hsu H., Wu H. and Sun B. Validation of ECMWF and NCEP-NCAR reanalysis data in Antarctica // Adv. Atmos. Sci. 2010. Vol. 27. P. 11511168.

Yu L., Zhong S. and Sun B. The Climatology and Trend of Surface Wind Speed over Antarctica and the Southern Ocean and the Implication to Wind Energy Application // Atmosphere. 2020. Vol. 11(1). 108. https://doi.org/10.3390/atmos 11010108. 